、| 研究体制の開放性を堅持し、外国の科学者や 医療従事者の教育訓練に無用の障壁を設ける ことのないよう、心掛けなければならないと いうことであろう。ある程度の制限は必要で あるが、科学技術を管理する取り組みは、疾 患発生を把握して封じ込めるための新たな試 験や治療法の開発など、科学の進歩による安 全保障推進の必要性と調和したものでなけれ ばならない。

そのようなことをすれば機密性の高い情報 や技術をテロリストに渡すことになると主 張する人もあろうが、これによってその種の 危険性がさほど増すことはない。規制があっ ても、それなりの費用で生物兵器を研究した いと考える者はいるものである。旧ソビエト の細菌戦研究の第一人者であったKen Alibek は、イランや北朝鮮などの国々がかつての 同僚たちを迎え入れたと話している 5 。実際の ところ、アメリカの科学を管理するだけで生 物兵器技術の流出を阻止することはできない のである。

それどころか、アメリカの科学は外国出身 の科学者に大きく依存しており、科学に関し て孤立主義を推し進めることは対生物テ口研 究の妨げとなるであろう。科学に関する情報 や事物の入手規制が研究に課す明らかな障壁 はともかく、科学面での外国人の養成を規制 すれば、対象国では疾患発生の把握と封じ込 めに重要な技術、つまり生物テロに対する全 世界的戦略の力ギとなるものを確立すること が遅れるだろう。求められているのは科学面 で人材を養成して全世界に広めることであ り、科学に関して孤立化を図ることではな い。

筆者の Thomas Mayは、ウィスコンシン医科大 学 (Medical College of Wisconsin, Milwaukee, Wisconsin 53226, USA) に所属している。

1. World Health Organization http://www.who.int/csr/sars/country/ table2003_09_23/en

2. Clarke, R. Against All Enemies: Inside AmericaÅfs War on Terror, Ch. 7 (Free Press, New York, 2004).

3. US Department of State. National Strategy for Combating Terrorism (February 2003). http://usinfo.state.gov/topical/pol/terror/strategy/\#intro

4. Rudman,W. et al. Emergency Responders: Drastically Underfunded, Dangerously Unprepared. Report of an Independent Task Force Sponsored by the Council on Foreign Relations (2003).

5. Alibek, K. \& Handelman, S. Biohazard, Ch. 20 (Hutchinson, London, 1999).

\title{
私たちは時間には追いつけない
}

自分の言つたことを理解するまでの間に、脳の中では何が起こっているのか。

原文：Time waits for no man

Nature Vol.429(243-244)/20 May 2004; www.naturejpn.com/digest

Mind Time: The Temporal Factor in Consciousness

by Benjamin Libet

Harvard University Press: 2004. 288 pp.

$\$ 29.95, £ 19.95, € 27.70$

\section{Kevan Martin}

「こ】が発したあなたへの愛の言葉を、私 1】自身が実際に耳にするまでの間、私 はあなたを愛していることに気づかなかっ た。何ということをロにしてしまったのだろ う』と一瞬思った。だが次の瞬間、それが真実 であることに私は気づいたのだつた」

バートランド・ラッセルは、オットリン・モ レルとの深夜の会話をこのように緅ってい る。この一節は、本書、すなわち意識における 時間的因子に関するBenjamin Libetの論文集 の基本命題をとらえている。Libet は長い間、 さまざまな実験を行ってきた。本書はその結 果に検討を加えたもので、これらの実験結果 によってラッセルの正当性が証明されると著 者は考えている。「現実の事象は、私たちがそ れを意識的に認識する約 0.5 秒前に発生して いる」というのが著者の基本命題だ。残念なが ら、私たちは絶対に現実に追いつくことがで きないのだ。

神経生物学者と心理学者による認識と意識 の研究は、今では研究の主流となっており、若 手研究者でも意識についての研究を進めれ ば、十分な予算を得てキャリアを積むことが できる。だが、そうではない時代もあった。著 者は大学での終身在職権を得て、研究テーマ を「意識」に切り替える踏ん切りがついた、と Francis Crickの意識に関する著書 The Astonishing Hypothesis (Simon \& Schuster, 1994)には記されている。この研究テーマの 変更は、私たちにとつては幸運な出来事だっ た。本書は、著者のこれまでの研究成果の回 顧展のようなものだ。ちょつとした先祖返り の趣があり、この研究分野に関して最近出版 される体裁の良い書物というよりも、著者の 指導教官だったJack Ecclesの初期の著作物に
近いものがある。しかし、いつたん読み始め れば、すぐに著者の熱心な個人指導に引き込 まれるという清新な作りの書物である。

著者にとつて脳神経外科医Bertram Feinstein と共同研究ができたことは幸運だった。この 共同研究で著者は、局所麻酔をかけられて意 識のある状態で脳外科手術を受けている患者 の大脳新皮質を調べることができた。また著 者は、体性感覚野を電気的に刺激すると、皮 膚の特定位置での触覚を意識的に知覚できる というWilder Penfield とHerbert Jasperの発 見も利用した。

著者の最初の発見は、パルス列による刺激 を200〜 500 ミリ秒間続けななければ、触覚が 意識的に知覚されないということだった。こ の時間的なずれ(「mind time」)から、著者は、 「time-on 説」を提唱するようになった。この 仮説によれば、意識的な知覚体験をするため には適切な脳の活動が 500 ミリ秒以上続くこ とを要し、脳の活動時間がそれより短いと無 意識の精神機能があらわれる可能性が生じる とされる。極めて速い反応時間の事例、例え ば陸上競技の $100 \times$ メトル走の一流ランナー の足が、スターターのピストルの発射からわ ずか130ミリ秒後にスターティングブロック から離れていることを説明するためには、こ の仮説の後半部分が必要となる。この事例で は、一流の短距離走者は、スターティングブ ロックから足が離れた後にピストルの発射を 認識することが示唆されている。しかし脳外 科手術を受けている患者の脳の状態をもと に、世界新記録を樹立するような運動選手の 脳の状態を本当に推定できるものだろうか。

視覚系の場合には、人間の視覚野を電気的 に刺激しても、眼内閃光という小さな光の点 ぐらいしか生じない。これは、1960年代前半 に Giles Brindley によって発見された。また Bill Newsomeたちは、サルのMT という視覚 野を直接電気的に刺激した時にサルの運動知 覚が影響を受けるのは、電気的刺激と現実の》 


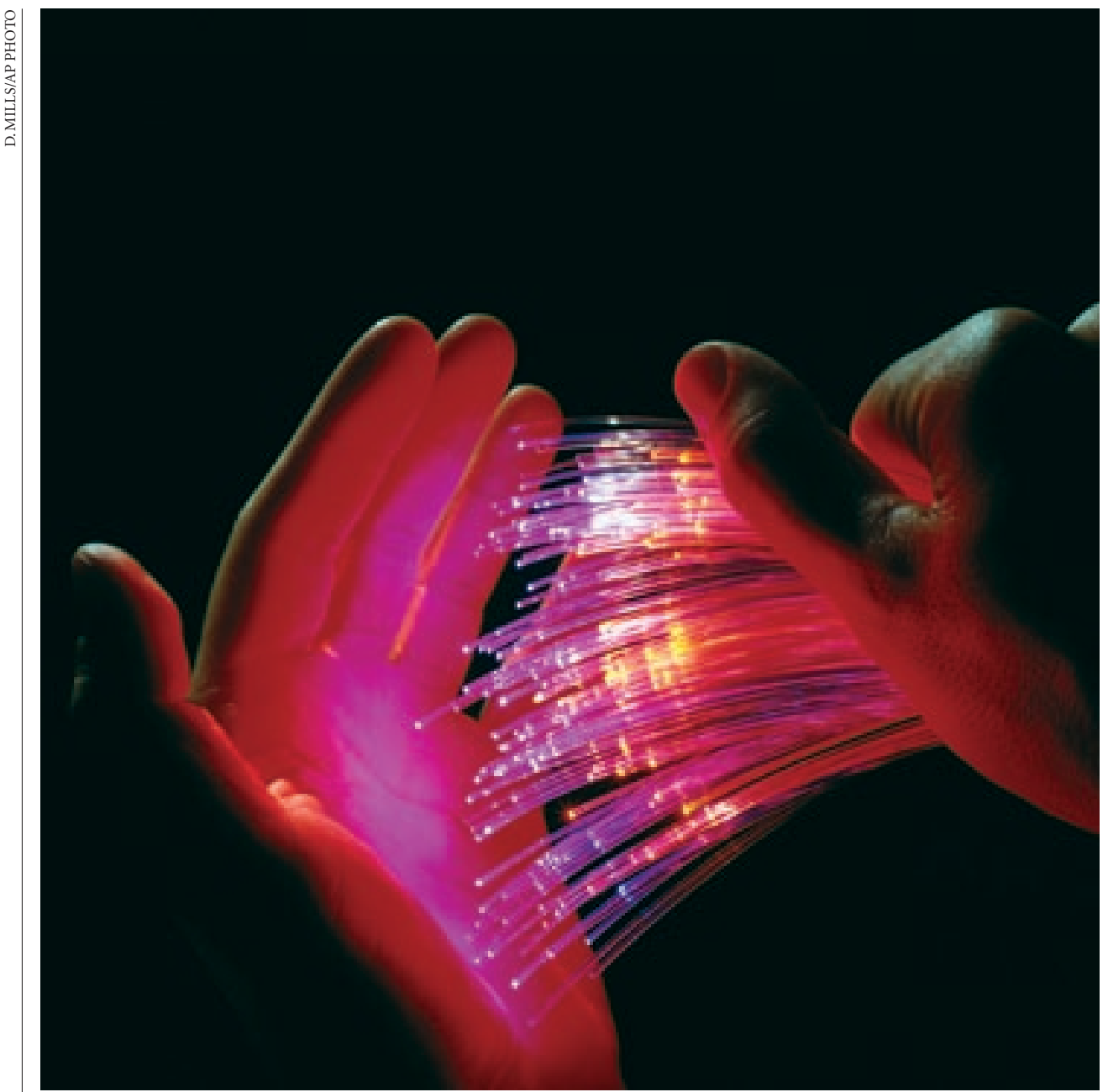

善のことは、乗っている高級車が、 時々違う方向に曲がろうとする時 に、ハンドルに手を伸ばすことのよ うに思われる。これは、それほど奇 妙なことではないかもしれない。一 流の音楽家が披露する熟練の技は、 頭で考えるより速いスピードで行わ れると考えられるからだ。

著者の研究によって恩恵を受け ているのが、哲学者たちだ。確かに 著者の実験と Larry Weiskrantzの 盲視の発見は、実験心理学が現代の 心の哲学に貢献した顕著な例と言 わざるを得ない。第一次視覚野に広 範囲の損傷がある人間とサルは、臨 床的には目が見えないのだが、 Weiskrantzは、このような人間とサ ルに物体の位置と形の推測を強制す る実験を行って、予想以上に正確な 推測が得られることを発見した。と ころが哲学者たちは、著者の才能を Weiskrantzほど高く評価しなかっ た。特に Paul Churchland、Ted HonderichとDaniel Dennettは、著 者の実験方法、実験結果や考え方を 攻撃した。(公正を期すならば、これ

視覚刺激を組み合わせた場合だけであること を発見した。直接的な電気的刺激だけでは、知 覚は生じない。あるいは少なくともサルが報 告できるような知覚は生じない。そのため、動 物モデルを使って、このテーマを研究するこ とは難しかった。

皮膚に触れることで感覚神経に生じる単一 インパルスは検出可能であることから、著者 の実験結果に対する一つの批判として、脳を 刺激する実験における大脳皮質活性化の時 空間的パターンが、かなり粗い点が指摘され ている。通常は皮膚の一領域によって生じる ニューロン活動が実験において人工的に引き 起こされているため、脳は、単にその活動を 文字通り理解しようとべストを尽くしている だけとも考えられる。そのためには脳神経 プログラムによる解釈が必要となって、通常 よりも時間がかかっているのかもしれない のだ。

著者の学説の中で最も物議をかもしている のは、「人間は刺激を直ちに認識していると主 観的に考えているため、主観的な夕イミング
とニューロンのタイミングは分離してしまっ ている」という考え方だ。さまざまな実験結果 に基づき、著者は、刺激を直ちに認識してい るという感覚は幻想であり、その原因は、私 たちが最初の大脳皮質での活動を基準に経験 のタイミングを考えている点にあると考えて いる。大脳皮質の活動は、実際に皮膚に触れ てから約10〜30ミリ秒後に生じているのだ。 このような正確な時間的計算のすべてが行わ れる神経メカニズムについては、もちろんの ことながら解明が進んでいない。

よく言い間違いをする読者にとっては慰め になるかもしれないが、私たちが行動の意思 をもってから、実際に行動を起こす原因とな る脳内事象が発生するまでに300～500ミリ 秒の遅れがあり、これは感覚事象の場合と同 じなのだ。こう考えると、ドッペルゲンガー (本人の分身) というゾンビが運転する高級車 の中で「意識的な自己」が後部座席でのんびり と座っているように思え、当然のことながら 「実際に意図をするのは誰なのか」という難問 に突き当たる。この場合、私たちができる最
らの哲学者たちは、お互いを攻撃しあっても いた。)彼らが困惑したのは、著者が、意識の 役割について、ときどき行動を拒否するよ うなオブザーバーとしての役割に追いやって しまった点だった。この著者の考え方は、身 体の機構が心によって制御されているとする デカルト学派の考え方、そして心亡脳内事象 を同視する唯物論的な考え方のいずれをも危 うくする内容だったからだ。

もちろん著者も、批判には答えている。し かし批判に答えるために考え出した新しい 学説では、脳から生じる「意識的な精神野 (conscious mental field)」という形で幽霊を 呼び戻してしまっているのだ。これは行き過 ぎかもしれない。本書に示された命題に賛成 するかどうかは別としても、著者の先駆的な 実験成果が、確かに私たちに刺激を与えるも のであったことは認めなければならない。

評者のKevan Martinは、ETH/チューリッヒ大学 ニューロインフォマティクス研究所 (Institute of Neuroinformatics, ETH/University of Zurich, Winterthurerstrasse 190, Zurich 8057, Switzerland) に所属している。 